\title{
Inhibition of astroglial NF-kappaB enhances oligodendrogenesis following spinal cord injury
}

\author{
Valerie Bracchi-Ricard ${ }^{1 \dagger}$, Kate L Lambertsen ${ }^{1,2 \dagger}$, Jerome Ricard ${ }^{1}$, Lubov Nathanson ${ }^{3}$, Shaffiat Karmally ${ }^{1}$, \\ Joshua Johnstone ${ }^{1}$, Ditte G Ellman², Beata Frydel ${ }^{1}$, Dana M McTigue ${ }^{4}$ and John R Bethea ${ }^{{ }^{*}}$
}

\begin{abstract}
Background: Astrocytes are taking the center stage in neurotrauma and neurological diseases as they appear to play a dominant role in the inflammatory processes associated with these conditions. Previously, we reported that inhibiting NF-KB activation in astrocytes, using a transgenic mouse model (GFAP-IKBa-dn mice), results in improved functional recovery, increased white matter preservation and axonal sparing following spinal cord injury (SCI). In the present study, we sought to determine whether this improvement, due to inhibiting NF-KB activation in astrocytes, could be the result of enhanced oligodendrogenesis in our transgenic mice.
\end{abstract}

Methods: To assess oligodendrogenesis in GFAP-IKBa-dn compared to wild-type (WT) littermate mice following SCI, we used bromodeoxyuridine labeling along with cell-specific immuno-histochemistry, confocal microscopy and quantitative cell counts. To further gain insight into the underlying molecular mechanisms leading to increased white matter, we performed a microarray analysis in naïve and 3 days, 3 and 6 weeks following SCI in GFAP-IkBa-dn and WT littermate mice.

Results: Inhibition of astroglial NF-KB in GFAP-IKBa-dn mice resulted in enhanced oligodendrogenesis 6 weeks following $\mathrm{SCl}$ and was associated with increased levels of myelin proteolipid protein compared to spinal cord injured WT mice. The microarray data showed a large number of differentially expressed genes involved in inflammatory and immune response between WT and transgenic mice. We did not find any difference in the number of microglia/leukocytes infiltrating the spinal cord but did find differences in their level of expression of toll-like receptor 4. We also found increased expression of the chemokine receptor CXCR4 on oligodendrocyte progenitor cells and mature oligodendrocytes in the transgenic mice. Finally TNF receptor 2 levels were significantly higher in the transgenic mice compared to WT following injury.

Conclusions: These studies suggest that one of the beneficial roles of blocking NF-KB in astrocytes is to promote oligodendrogenesis through alteration of the inflammatory environment.

Keywords: NF-kappaB, Spinal cord injury, Astrocyte, Oligodendrocyte, Microglia, CXCR4, TNFR2, Toll-like receptor

\section{Background}

Spinal cord injury (SCI) is a devastating condition affecting millions of people worldwide. Following the initial trauma to the spinal cord, with loss of cells at the site of impact, a second phase injury occurs characterized in part by secretion of cytokines and chemokines produced at the lesion site leading to recruitment of peripheral leukocytes to the injury [1]. While an inflammatory

\footnotetext{
* Correspondence: JBethea@miami.edu

${ }^{\dagger}$ Equal contributors

${ }^{1}$ The Miami Project to Cure Paralysis, University of Miami, Miami FL 33136, USA

Full list of author information is available at the end of the article
}

response is necessary to clear debris at the site of injury it, if uncontrolled, leads to an enlargement of the initial lesion, with additional axonal damage, oligodendrocyte cell death and demyelination with concomitant increased loss of neurological function. The loss of oligodendrocytes, however, may be replaced by proliferating nerve/ glial antigen $2^{+}$(NG2) cells, also known as oligodendrocyte precursor cells (OPCs) [2]. These OPCs are able to migrate to the injury site and differentiate into mature myelinating oligodendrocytes if the environment is permissive [3]. The lack of effective remyelination is often due to the presence of oligodendrocyte differentiation 
inhibitors in the injury environment, which can originate from astrocytes, demyelinated axons or myelin debris $[4,5]$. Until recently, the contribution of astrocytes to demyelinating diseases was underestimated. However, our laboratory and others have now established a prominent role of astrocytes in vivo in the pathogenesis of experimental autoimmune encephalomyelitis (EAE) [6-8] and axonal degeneration [9] and in vitro an increasing number of astroglial-derived factors have been identified that modulate myelination processes $[7,10,11]$.

One of the ways astrocytes respond to injury is by producing cytokines and chemokines, many of which are regulated by NF-kB. To study the role of astroglial $\mathrm{NF}-\mathrm{kB}$ in the pathogenesis of $\mathrm{SCI}$, we previously gen-

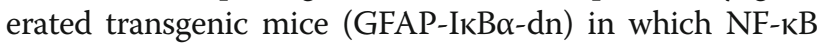
is specifically inactivated in astrocytes by overexpression of a truncated form of the inhibitor I $\mathrm{K} B \alpha(\mathrm{I} \kappa \mathrm{B} \alpha-\mathrm{dn})$ under the control of the glial fibrillary acidic protein (GFAP) promoter [12]. In this previous study, we demonstrated that blocking NF- $\mathrm{KB}$ activation in astrocytes resulted in reduced expression of cytokines and chemokines such as CXCL10, CCL2 and transforming growth factor beta, and in a smaller lesion volume and increased white matter sparing along with a significant improvement in locomotor function following SCI. Further studies showed that inhibition of astroglial NF- $\mathrm{kB}$ promoted axonal sparing and sprouting of supraspinal and propriospinal axons, which are essential for locomotion [13]. In a brain injury model astroglial NF- $\mathrm{kB}$ was also found to play a central role in directing immune-glial interactions by regulating the expression of CCL2 through STAT2 [9]. One explanation for the observed larger volume of white matter in our transgenic mice could be a reduction in oligodendrocyte cell death or an increase in oligodendrogenesis. Here, we are addressing the role of astroglial NF- $\mathrm{B}$ in regulating oligodendrogenesis in the chronically injured spinal cord.

\section{Methods}

Mice

Adult (3 to 4 months) female GFAP-IkB $\alpha-d n$ (IkB $\alpha-d n)$ transgenic mice were generated and characterized in our laboratory [12]. All animals, $\mathrm{I} \kappa \mathrm{B} \alpha-\mathrm{dn}$ and wild-type (WT) littermates (LM), were kept as a colony in a virus/ antigen-free environment at the University of Miami Miller School of Medicine, Miami, FL, USA. I $\mathrm{kB} \alpha-\mathrm{dn}$ mice were obtained by breeding heterozygous I $\mathrm{kB} \alpha-\mathrm{dn}$ males with WT females. Mice were housed under diurnal lightning conditions and allowed free access to food and water.

\section{Induction of spinal cord injury}

Surgeries were performed at the Animal and Surgical Core Facility of the Miami Project to Cure Paralysis according to protocols approved by the Institutional Animal Care and Use Committee of the University of Miami. Contusion injury was induced with the Infinite Horizon Device (Precision Systems and Instrumentation LLC, Kentucky, USA). Female IkB $\alpha$-dn (21.5 $\pm 2.7 \mathrm{~g})$ and WT LM (21.0 $\pm 2.8 \mathrm{~g})$ mice were anesthetized intraperitoneally (i.p.) using a ketamine $(100 \mathrm{mg} / \mathrm{kg}$, VEDCO Inc., Saint Joseph, MO, USA)/xylazine $(10 \mathrm{mg} / \mathrm{kg}$, VEDCO) cocktail, and a laminectomy was performed at the vertebral level T9. The contusion device was lowered onto the spinal cord at a predetermined impact force of 50 kdynes (moderate injury) and the mice were injured by a rapid displacement of the impounder resulting in a spinal cord displacement of 400 to $500 \mu \mathrm{m}$. Immediately after surgery, mice were sutured and injected subcutaneously (s.c.) with $1 \mathrm{ml}$ lactated Ringer's Injection USP (B. Braun, L7502, Bethlehem, PA, USA) to prevent dehydration and housed separately in a recovery room, where their post-surgical health status was observed. Thereafter, mice were returned to the conventional animal facility, where they were observed bi-daily for activity level and general physical condition. Manual bladder expression was performed twice a day until bladder function was regained. In addition, mice received s.c. prophylactic injections of antibiotic gentamicin (40 mg/kg, Hospira Inc., Lake Forest, IL, USA) for 7 days following SCI to prevent urinary tract infections. Mice were allowed 3 days, 3, 6 or 7 weeks survival.

\section{Bromodeoxyuridine injections and tissue processing}

Mice in the 7 weeks survival group were injected i.p. with bromodeoxyuridine (BrdU; $50 \mu \mathrm{g} / \mathrm{g}$ body weight; Sigma, St. Louis, MO, USA) once a day for 7 days starting at week 5 post-SCI and were allowed to survive for 1 more week. Then the mice, naïve, 3 days, 6 and 7 weeks survival, were deeply anesthetized and perfused through the left ventricle using ice cold $0.01 \mathrm{M}$ PBS followed by ice cold $4 \%$ paraformaldehyde (PFA) in PBS. The spinal cords were post-fixed in 4\% PFA followed by immersion in $25 \%$ sucrose in PBS overnight. Spinal cords were cut into 1-cm segments centered on the injury site and then embedded in optimal cutting temperature (OCT) compound (VWR International, Arlington Heights, IL, USA), frozen and cut into 10 series of $25 \mu \mathrm{m}$ transverse cryostat sections. Sections were stored at $-20^{\circ} \mathrm{C}$ until further use.

\section{Immunohistochemistry}

Antibodies used for immunohistochemical staining were rat anti-mouse CD11b (1:600, AbDSerotec, Hercules, CA, USA, MCA711 clone 5C6) and rabbit anti-NG2 (1:500, Chemicon, Billerica, MA, USA, AB5320). Isotype control antibodies were rabbit immunoglobulin (Ig)G (1:20,000, DakoCytomation, Carpinteria, CA, USA, X0903) and rat $\operatorname{IgG}_{\mathrm{b}}$ (1:600, Biosite, Plymouth Meeting, PA, USA, 


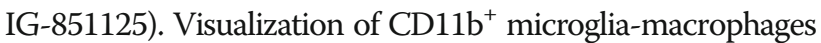
was performed using the three-step biotin-streptavidinhorseradish peroxidase technique described by Lambertsen and colleagues, 2001 [14]. Visualization of $\mathrm{NG}^{+}$ OPCs was performed using peroxidase-labeled "readyto-use" EnVision ${ }^{+}$polymer (K4300, DakoCytomation) according to the manufacturer's instructions on spinal cord sections demasked using 0.5\% Pepsin (SigmaAldrich, P-7012) in $\mathrm{HCl}$ and $\mathrm{H}_{2} \mathrm{O}$ for 10 minutes at $37^{\circ} \mathrm{C}$. Sections were counterstained using Hematoxylin Gills or Toluidine blue. Isotype controls were devoid of staining (not shown).

\section{Estimation of the total number of $\mathrm{CD} 11 \mathrm{~b}^{+}$and $\mathrm{NG}^{+}$cells} Using an approximated stereological counting technique unaffected by shrinkage/tissue resorption [15], we estimated the total number of $\mathrm{CD}_{11 b^{+}}$and $\mathrm{NG}^{+}$cells in the spinal cord of naïve $I_{k} B \alpha-d n$ and WT mice and the total number of $\mathrm{CD}_{11 \mathrm{~b}^{+}}$cells in $\mathrm{I} \kappa \mathrm{B} \alpha-\mathrm{dn}$ and WT mice that had survived 3 days and 6 weeks after SCI. Briefly, cells with a clearly identifiable $\mathrm{H} \& \mathrm{E}$ or Toluidine Blue stained nucleus in conjunction with a detectable immunohistochemical signal were counted on approximately 13 sections in naïve cords and at 3 days, and on $17 \mathrm{sec}-$ tions 6 weeks after injury separated by $250 \mu \mathrm{m}$ from each animal, using a $100 \times$ objective and a $2,470 \mu \mathrm{m}^{2}$ frame area stepping $150 \mu \mathrm{m} / 150 \mu \mathrm{m}$ in the XY-position using the CAST Grid System from Olympus (Ballerup, Denmark). The total number $(\mathrm{N})$ of cells in each animal was estimated using the formula: Estimate of $\mathrm{N}=\Sigma \mathrm{Q} \times$ $(1 / \mathrm{ssf}) \times(1 / \mathrm{asf}) \times(1 / \mathrm{tsf})$, where $1 /$ tsf is the thickness sampling fraction $(1 /$ tsf $=1), 1 /$ ssf the sampling section fraction $(1 / \mathrm{ssf}=10)$, and 1 /asf the area sampling fraction $(22,500 / 2,470)$ as previously described [16]. In naïve mice and for the time point of 3 days we, for consistency, analyzed a total of $3.25 \mathrm{~mm}$ long piece of mouse spinal cord, $1.625 \mathrm{~mm}$ on pre- and post-epicenter. For the time point of 6 weeks we analyzed a $4.25 \mathrm{~mm}$ long piece of mouse spinal cord, $2.125 \mathrm{~mm}$ on both sides of the epicenter.

\section{Estimation of the lesion and white matter volumes}

The lesion volume and the white matter volume were estimated on Luxol Fast Blue serial sections counter stained with $H \& E$ using the Neurolucida software (MBF Bioscience, Williston, VT, USA) as previously described [12].

\section{Immunofluorescent staining}

For BrdU immunofluorescent staining, cryostat sections were thawed at room temperature for 5 minutes, rinsed in $1 \mathrm{X}$ PBS, and processed for antigen retrieval using $2 \mathrm{~N}$ $\mathrm{HCl}$ for 30 minutes at $37^{\circ} \mathrm{C}$. The sections were then neutralized for 10 minutes in $0.1 \mathrm{M}$ sodium borate $(\mathrm{pH} 8.5)$ and rinsed in 1X PBS. After blocking 30 minutes in 5\% BSA/5\% normal goat serum (NGS)/0.3\% Triton X100/ PBS, rat anti-BrdU antibody (1:200, Novus Biologicals, Littleton, CO, USA; diluted in $4 \% \mathrm{BSA} / 3 \% \mathrm{NGS} / 0.1 \%$ Triton X100/PBS) was applied to the sections in combination with either mouse anti-adenomatous polyposis coli (APC; clone CC1) antibody (1:500, Calbiochem, Billerica, MA, USA) or rabbit anti-NG2 antibody (1:500, Chemicon), and incubated overnight at $4^{\circ} \mathrm{C}$. For triple immunostaining we used rat anti-BrdU (1:200, Novus Biologicals) and rabbit anti-Olig2 (1:500, Millipore, Billerica, MA, USA) with either mouse anti-NG2 (1:200, Millipore) or mouse anti-APC (1:500, Calbiochem). Following extensive rinses in $1 \mathrm{X}$ PBS, Alexa-conjugated secondary antibodies (1:500, Molecular Probe, Grand Island, NY, USA) were applied for $30 \mathrm{~min}$ at room temperature. Sections were finally rinsed and mounted with Vectashield (Vector Laboratories, Burlingame, CA, USA). To estimate the number of $\mathrm{BrdU}^{+} / \mathrm{CC}^{+}, \mathrm{BrdU}^{+} / \mathrm{NG}^{+}$, and total $\mathrm{CC}^{+}$-cells following SCI, serial sections were counted using Zeiss Axiovert 200M fluorescent microscope (63X objective; Thornwood, NY, USA) and Stereo Investigator software (MicroBrightField, Williston, VT, USA) for unbiased stereological estimation of cell numbers. For each section a $50 \times 50 \mu \mathrm{m}$ counting frame and a $120 \times 120 \mu \mathrm{m}$ grid was used to count the cells at $250 \mu \mathrm{m}$ intervals. A total number of 11 sections, centered on the lesion site, were counted. For the number of $\mathrm{CC}^{+}$cells in the naïve thoracic spinal cord, a total number of 5 sections were counted.

For CXCR4 immunostaining, thawed cryostat sections were fixed and permeabilized in ice-cold acetone for 10 minutes at $-20^{\circ} \mathrm{C}$, then rinsed in PBS and blocked for 1 hour in $10 \% \mathrm{NGS} / \mathrm{PBS}$ and 30 minutes in 5\% BSA/PBS. Sections were then incubated overnight with rabbit antiCXCR4 antibody (1:500, Abcam, Cambridge, MA, USA) diluted in $5 \% \mathrm{BSA} / 1 \% \mathrm{NGS} / \mathrm{PBS}$ in combination with either mouse anti-GFAP (1:500, BD Pharmingen, San Jose, CA, USA) or mouse anti-APC (1:500, Calbiochem) antibodies. Alexa-conjugated secondary antibodies (1:500, Molecular Probes) diluted in 5\% BSA/1\% NGS/PBS were applied to the rinsed sections for 30 minutes at room temperature. Then sections were rinsed and mounted with Vectashield with 4',6-diamidino-2-phenylindole (DAPI) (Vector Laboratories). For toll-like receptor 4 (TLR4; 1:50, Santa Cruz, Dallas, TX, USA) and TNF receptor 2 (TNFR2; 1:200, Santa Cruz), a similar protocol was used except that the sections were permeabilized and blocked in 5\% BSA/5\% NGS/0.3\% Triton X100/PBS. Nuclei were visualized using a DAPI counterstain. Images were obtained with an Olympus FluoView 1000 confocal microscope.

\section{Total RNA isolation}

Total RNA was isolated from spinal cord samples $(1.5 \mathrm{~cm}$ centered on the lesion site) using TRIzol reagent 
(Invitrogen, Grand Island, NY, USA) according to the manufacturer's directions. Precautions were taken to preserve RNA integrity during the isolation, including rapid dissection on ice with RNase-free dissecting tools followed by flash-freezing in liquid nitrogen of the spinal cord segment sample as previously described by Brambilla and colleagues [6]. RNA integrity was determined with the Bioanalyzer 2100 (Agilent Technologies, Santa Clara, CA, USA).

\section{Microarray analysis and data processing}

Microarray experiments were conducted at the University of Miami DNA and Microarray Core Facility (http://www. mihg.org/weblog/core_resources/2007/11/microarray-andgene-expression.html) using Agilent Whole Mouse Genome Oligo microarrays (Agilent Technologies). Arrays were scanned at a $5 \mu \mathrm{m}$ resolution using a GenePix 4000B scanner (Axon Instruments at Molecular Devices) and images analyzed with the software GenePix Pro 6.1 (Axon Instruments at Molecular Devices, LLC, Sunnyvale, CA, USA). Extracted data were transferred to the software Acuity 4.0 (Axon Instruments at Molecular Devices) for quality control. Features for further analysis were selected according to the following quality criteria: at least $90 \%$ of the pixels in the spot with intensity higher than background plus two standard deviations; less than $2 \%$ saturated pixels in the spot; signal to noise ratio (ratio of the background subtracted mean pixel intensity to standard deviation of background) 3 or above for each channel; spot diameter between 80 and $110 \mu \mathrm{m}$; regression coefficient of ratios of pixel intensity 0.6 or above. To identify significantly expressed genes the $\mathrm{R}$ software LIMMA (Bioconductor, open source software at http:// www.bioconductor.org) [17] was used. "Within array" normalization was carried out with Lowess normalization and "between arrays" normalization with the "quantile" algorithm in the LIMMA package. Differential expression and false discovery rate (FDR) were assessed using a linear model and empirical Bayes moderated F statistics [18,19]. Genes with FDR below 1\% were considered statistically significant. All primary microarray data were submitted to the public database at the GEO website (http://www.ncbi. nih.gov/geo; record number: GSE46695). Selected genes were classified according to Gene Ontology category "biological process" using Onto-Express [20]. Pathway analysis was performed with WebGestalt [21]. Hierachical clustering was performed using GeneSpring 10.0 (Agilent Technologies). All experiments were performed in three replicates/groups/time points.

\section{Quantitative real-time PCR}

An aliquot of $2 \mu \mathrm{g}$ of spinal cord RNA from each time point was reverse transcribed using the omniscript RT-PCR kit (Qiagen, Valencia, CA, USA) as previously described [6]. qPCR was performed with the Rotor-Gene 3000 Real Time Cycler (Corbett Research, Valencia, CA, USA) on cDNA samples with TAQurate GREEN Real-Time PCR MasterMix (Epicentre Biotechnologies, Madison, WI, USA) as previously described [6] for the following genes: CXCR4 (forward primer: TGT GAC CGC CTT TAC CCC GAT AGC, reverse primer: TTC TGG TGG CCC TTG GAG TGT GAC), TLR4 (forward primer: TGC CCC GCT TTC ACC TC, reverse primer: ACC AAC GGC TCT GAA TAA AGT GT), Lingo-1 (forward primer: GAC TGC CGG CTG CTG TGG GTG TT, reverse primer: CCG GCG GCA GGT GAA GTA GTT GG), Sox17 (forward primer: CGG CGC AAG CAG GTG AAG, reverse primer: GGC TCC GGG AAA GGC AGA C), CNPase (forward primer: AGA TGG TGT CCG CTG ATGCTT AC, reverse primer: CTC CCG CTC GTG GTT GGT), CD11b (forward primer: GCC CCA AGA AAG TAG CAA GGA GTG, reverse primer: TAC GTG AGC GGC CAG GGT CTA AAG) and ICAM1 (forward primer: TGA GCG AGA TCG GGG AGG ACA G, reverse primer: GTG GCA GCG CAG GGT GAG GT). Relative expression was calculated by comparison with a standard curve after normalization to $\beta$-actin [6].

\section{Western blotting}

Spinal cords (1.5 cm centered on the injury site) were homogenized in $300 \mu \mathrm{l}$ radio immunoprecipitation assay buffer $(0.01 \mathrm{M}$ sodium phosphate $\mathrm{pH} 7.2,0.15 \mathrm{M} \mathrm{NaCl}$, $1 \%$ NP40, 1\% sodium deoxycholate, $0.1 \%$ SDS, $2 \mathrm{mM}$ EDTA) supplemented with complete protease inhibitor cocktail (Roche, Indianapolis, IN, USA), incubated for 30 minutes at $4^{\circ} \mathrm{C}$ on an end-over-end rotator, and centrifuged at $4^{\circ} \mathrm{C}$ for 10 minutes at $14,000 \mathrm{rpm}$. The supernatant was then transferred to a fresh tube on ice and an aliquot was used for protein quantification using the $D C$ Protein Assay (Biorad, Hercules, CA, USA). Equal amounts of proteins were resolved by SDS-PAGE on $10 \%$ or $15 \%$ gels, transferred to nitrocellulose membranes, and blocked in $5 \%$ nonfat milk in $0.1 \mathrm{M}$ Tris buffered salinetriton (TBS-T) for 1 hour at room temperature. Membranes were probed with an antibody recognizing either proteolipid protein (PLP; mouse monoclonal, Millipore, 1:250), CXCR4 (rabbit polyclonal, Abcam, 1:500), Foxc2 (mouse monoclonal, Santa Cruz, 1:500), TLR4 (mouse monoclonal, Santa Cruz, 1:200), TNFR2 (rabbit polyclonal, Santa Cruz, 1:200), CXCR7 (rabbit polyclonal, GeneTex, Irvine, CA, USA, 1:1000) followed by horseradish peroxidase-conjugated secondary antibody (GE Healthcare, Little Chalfont, Buckinghamshire, UK, 1:2000). Proteins were visualized with a chemiluminescent kit (ECL; GE Healthcare). Blots were also probed for $\beta$-actin (mouse monoclonal, Santa Cruz, 1:500) as a loading control. The data were analyzed using Quantity One software (Biorad). 


\section{Data analysis}

One-way or two-way analysis of variance (ANOVA) followed by the appropriate post hoc test and Student's $t$-test (one-tailed and two-tailed). Statistical analyses were performed using Prism 4.0b software for Macintosh, GraphPad Software, San Diego, CA, USA, www.graphpad. com. Data are presented as mean \pm SEM. Statistical significance was established for $P<0.05$.

\section{Results \\ Oligodendrogenesis is increased following spinal cord injury in mice lacking functional NF-KB signaling in astrocytes}

Based on our previous findings of a reduced lesion volume, increased white matter preservation and associated improvements in locomotor function 8 weeks following moderate contusion to the thoracic spinal cord in mice lacking astroglial NF-kB [12], we wanted to investigate the possibility that the observed increase in white matter is due, in part, to enhanced oligodendrogenesis. Since our GFAP-IkB $\alpha$-dn mice were generated 7 years ago and may have been affected by genetic drift over time, we decided to confirm by RT-PCR that the transgene $(I \kappa B \alpha-d n)$ was indeed still expressed in the spinal cord of our transgenic mice (Figure 1A). We also confirmed that, 6 weeks following SCI, GFAP-IKB $\alpha-\mathrm{dn}$ mice displayed a significantly smaller lesion volume, associated with a significantly larger white matter volume (Figure 1B-D). This was also reflected by a significant improvement of locomotor performance in the open field test, scored by the basso mouse scale [22] (IkB $\alpha-\mathrm{dn}$ : 5.4 vs WT: 4.1, $P<0.05$ ). Next, we investigated whether there were any abnormalities in the morphology of the spinal cord and in the total number of OPCs and mature oligodendrocytes, due to ex-

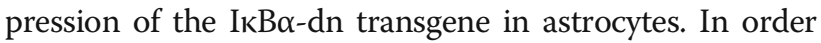
to do so, total numbers of $\mathrm{NG}^{+}$OPCs (Figure 1E, upper panel) and $\mathrm{CC}^{+}$oligodendrocytes (Figure 1E, lower panel) were estimated in spinal cord sections from naïve WT and I $\mathrm{I} B \alpha-\mathrm{dn}$ mice. We found that the spinal cords from naïve WT and I $\mathrm{KB} \alpha-\mathrm{dn}$ mice appeared morphologically identical [12] and displayed similar numbers of $\mathrm{NG}^{+}$OPCs (WT: 2,479 \pm 181 ; IkB $\alpha-\mathrm{dn}$ : $3,397 \pm 683, P=0.23$ ) and $\mathrm{CC}^{+}$oligodendrocytes (WT: $59,190 \pm 2,086 ;$ IкB $\alpha-d n: 61,540 \pm 2,447, P=0.504)$ (Figure 1E).

In order to investigate changes in oligodendrogenesis following SCI, we administered BrdU daily for 7 days starting the fifth week following injury and sacrificed the mice 2 weeks later (7 weeks post-SCI) so that the BrdUlabeled OPCs had time to differentiate into mature oligodendrocytes [2] (Figure 2A). To investigate changes in numbers of newly formed OPCs and newly formed mature oligodendrocytes, we performed double immunostaining for BrdU, and NG2 or CC1, respectively, and estimated the total number of $\mathrm{BrdU}^{+} \mathrm{NG}^{+}$and $\mathrm{BrdU}^{+} \mathrm{CC}^{+}$cells in $2-\mathrm{mm}$ long spinal cord segments 7 weeks after SCI. We found no significant difference in

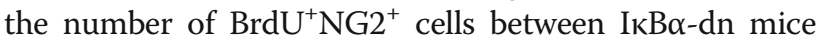
$(11,140 \pm 503)$ and WT mice $(10,640 \pm 679)(P=0.57)$ (Figure $2 \mathrm{~B}, \mathrm{C}$ ). However, we did find a significant increase in the number of $\mathrm{BrdU}^{+} \mathrm{CC}^{+}$cells in the injured spinal cord of IkB $\alpha$-dn mice $(20,550 \pm 3,043)$ compared to that of WT mice $(11,400 \pm 1,062)$ (Figure $2 \mathrm{D}, P<0.05$ ) suggesting that blocking astroglial NF- $\mathrm{B}$ promotes oligodendrogenesis. Furthermore, when looking at the distribution of the $\mathrm{BrdU}^{+} \mathrm{CC}^{+}$cells rostrally and caudally from the epicenter, we found significantly more $\mathrm{BrdU}^{+} \mathrm{CC}^{+}$cells around the epicenter in the I $\mathrm{B} \alpha-\mathrm{dn}$ mice compared to WT mice, suggesting that the microenvironment within or near the lesion core, in the I $\kappa B \alpha-d n$ mice, is more permissive for differentiation of OPCs into mature oligodendrocytes (Figure 2E). Triple immunofluorescence staining confirmed that $\mathrm{BrdU}^{+} \mathrm{NG}^{+}$and $\mathrm{BrdU}^{+} \mathrm{CC}^{+}$cells colocalized with Olig2 ${ }^{+}$cells, another marker for OPCs and mature oligodendrocytes [23] (Figure 2F). To further confirm increased oligodendrogenesis in the $I_{\kappa} B \alpha-d n$ mice, we estimated the total number of mature $\mathrm{CC}^{+}$oligodendrocytes in 2-mm long spinal cord segments 7 weeks after SCI. Supporting our finding of increasing numbers of mature $\mathrm{BrdU}^{+} \mathrm{CCl}^{+}$oligodendrocytes in IKB $\alpha-\mathrm{dn}$ mice (Figure 2D), we found significantly more $\mathrm{CC}^{+}$cells $(P=$ $0.04)$ in the injured spinal cord of IkB $\alpha$-dn mice $(155,800 \pm$ $13,490)$ compared to injured WT spinal cord $(104,300 \pm$ 6,356) 7 weeks after SCI (Figure 2G, left). These data were furthermore supported by findings of significantly increased PLP protein levels in the spinal cords of IKB $\alpha-\mathrm{dn}$ mice 6 weeks after injury compared to injured WT mice (Figure 2G, right), which further points to an increased oligodendrogenesis after SCI in IkB $\alpha$-dn mice. Collectively, these data demonstrate that inhibiting astroglial NF- $\mathrm{BB}$ enhances oligodendrogenesis following SCI.

\section{Microarray analysis of the spinal cord from wild-type and IKBa-dn mice following spinal cord injury}

To elucidate the molecular mechanisms leading to the observed increased oligodendrogenesis, we compared gene expression profiles using Whole Mouse Genome microarrays, which included 41,000 genes and transcripts from naïve and injured WT and IkB $\alpha-d n$ mice. The experiments were performed using three biological replicates per group using naïve animals as well as three different survival times - 3 days, 3 and 6 weeks post-SCI. We concentrated on genes with a fold-change greater than 2.0 and a FDR $<0.1 \%$. We identified 66 differentially expressed genes between naïve mice, 35 genes were differentially expressed 3 days after SCI, 108 genes were differentially expressed at 3 weeks and at 6 weeks 994 


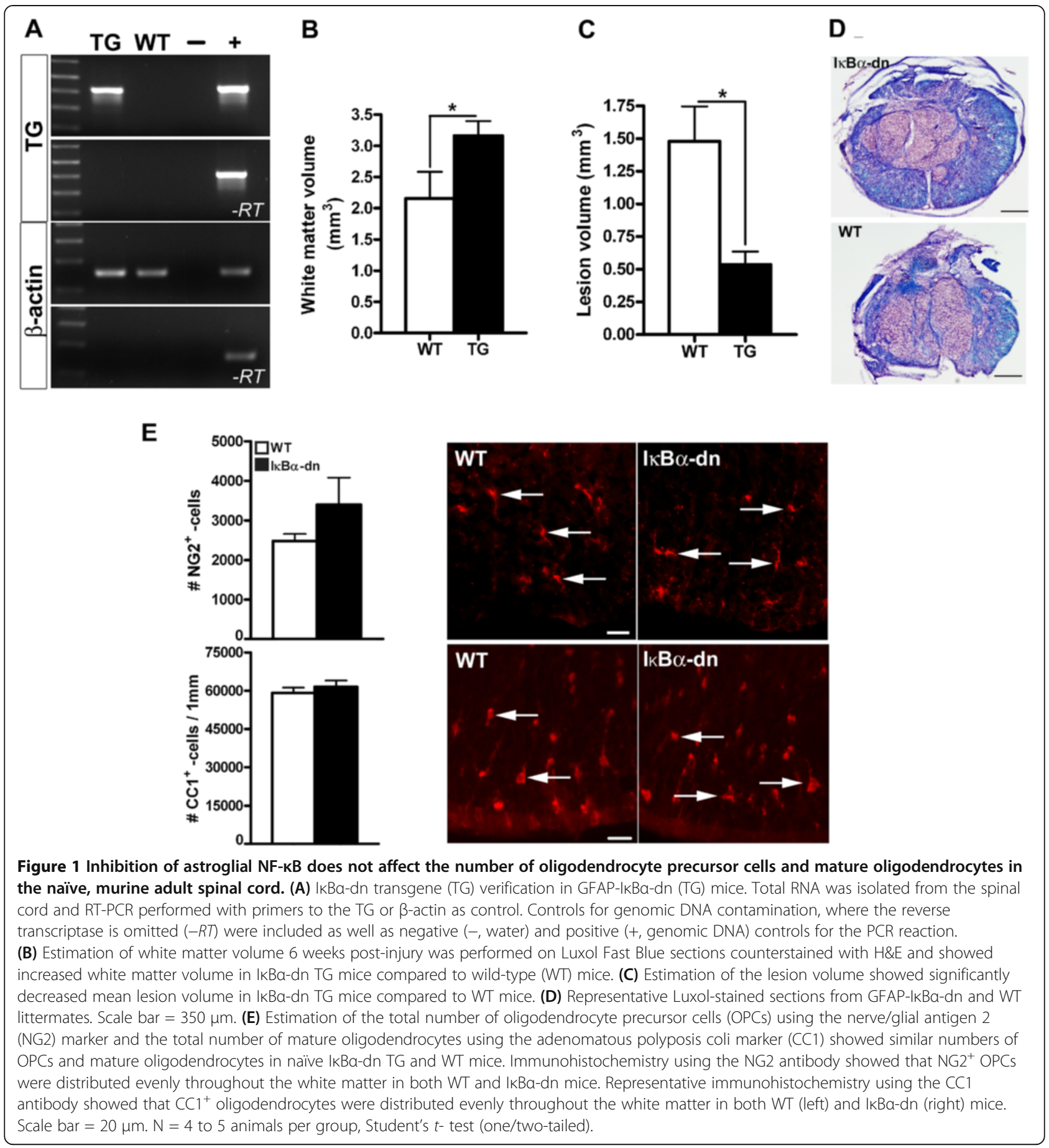

genes were found to be differentially expressed (Table 1). Significant changes were especially present 6 weeks after $\mathrm{SCI}$ in genes involved in inflammatory/immune responses, chemotaxis, motor axon guidance, axonal growth, cell death, signal transduction, and so on, all processes that may influence functional recovery. For a functional classification of a subset of transcripts 6 weeks after SCI please refer to Table 2 and The National Center for
Biotechnology Information Gene Expression Omnibus GSE46695 for a list of all transcripts. Relative transcript enrichment detected by microarrays was confirmed by qPCR for eight genes (Ki67, Sox17, CD11b, TLR4, CXCR4, Lingo-1, ICAM1 and CNPase) selected from the 6 weeks gene groups (Figure $3 \mathrm{~A}-\mathrm{H}$ ).

Thus far we have presented data suggesting that inhibiting NF- $\mathrm{kB}$ activation in astrocytes promotes an 

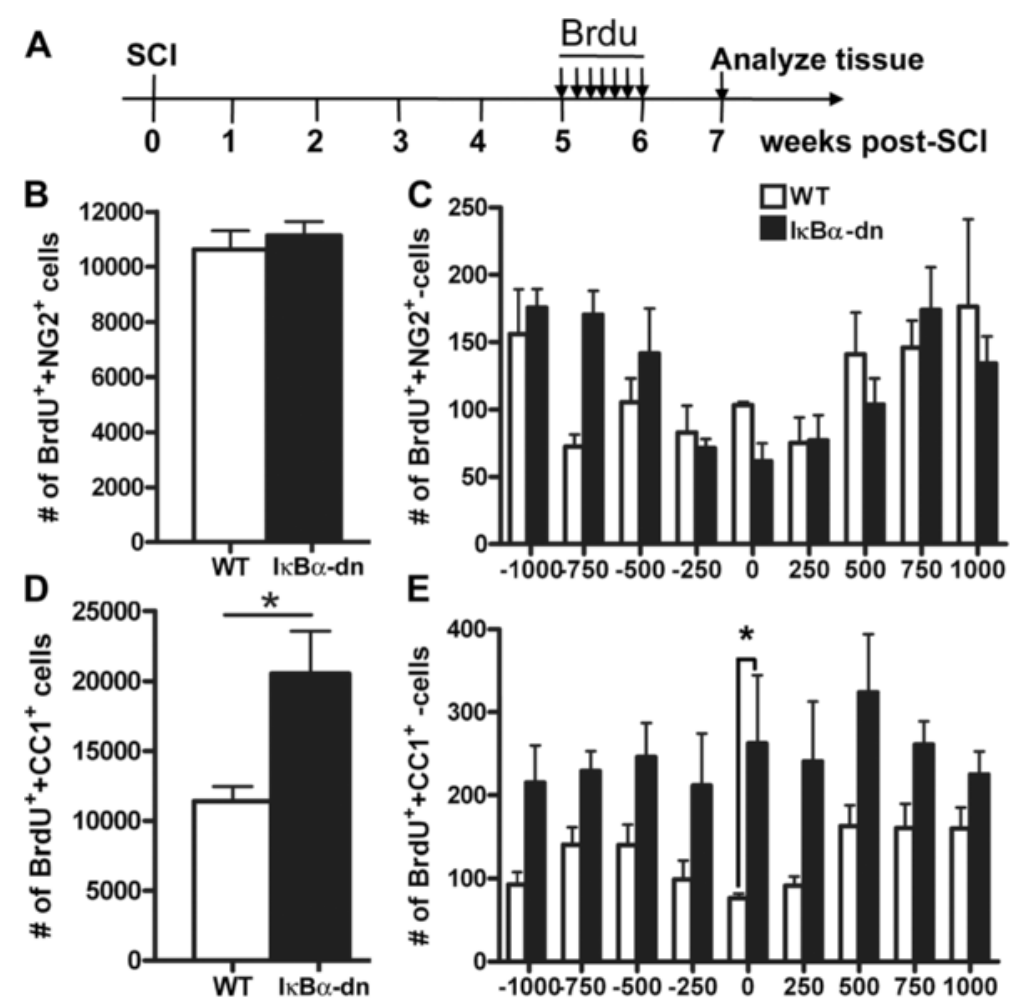

E

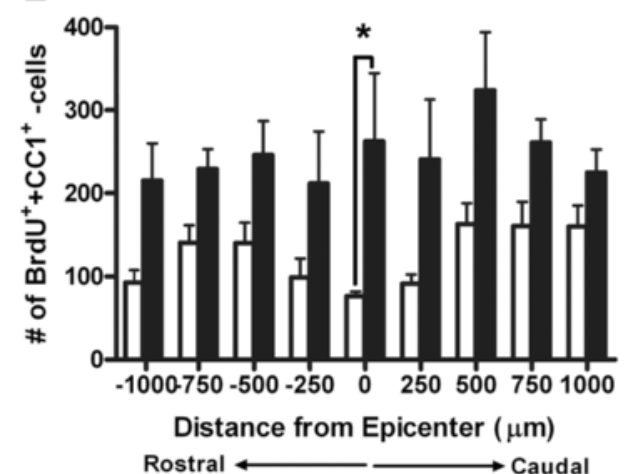

$\mathbf{F}$
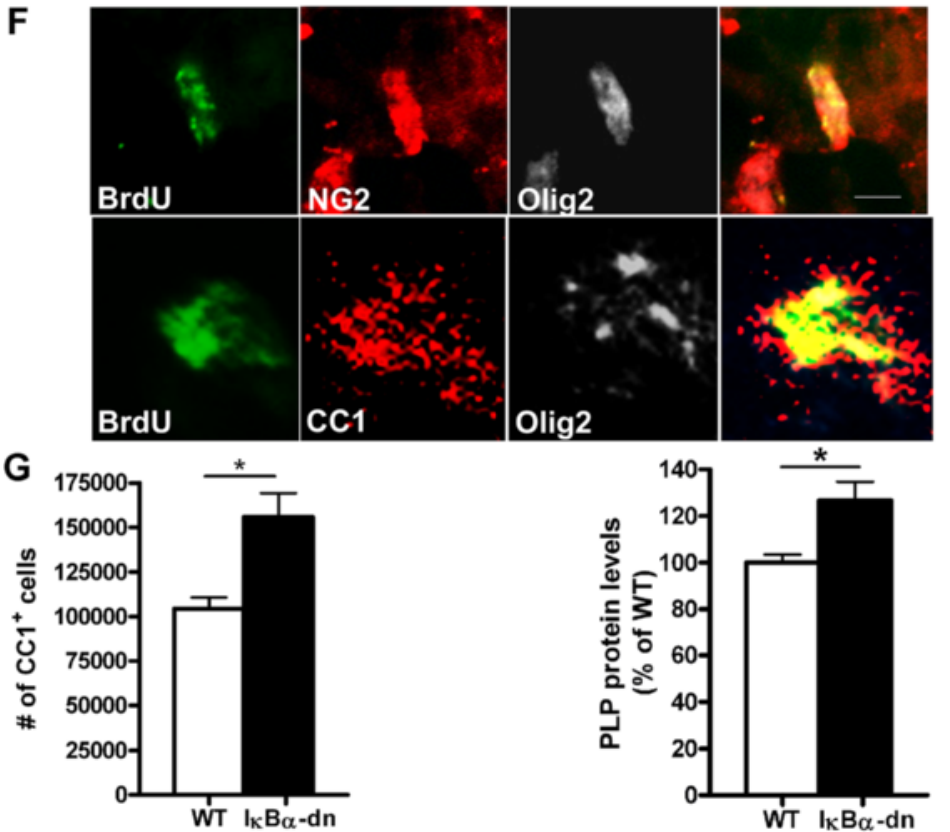

Figure $\mathbf{2}$ (See legend on next page.) 
(See figure on previous page.)

Figure 2 Oligodendrogenesis is increased in IKBa-dn mice lacking functional NF-кB signaling in astrocytes. (A) Mice were subjected to moderate spinal cord contusion at T9 and received bromodeoxyuridine (BrdU) injections once a day for 1 week starting 5 weeks post-injury. Spinal cord tissue (in total $2 \mathrm{~mm}$ centered on injury) was analyzed 7 weeks post-spinal cord injury (SCI). (B, C) The total estimated number of $\mathrm{BrdU}^{+} \mathrm{NG}^{+}$cells using Stereo Investigator software in a 2-mm segment of spinal cord centered on the site of injury was similar between wild-type (WT) and IkBa-dn mice (B) with a similar distribution over the injured spinal cord (C). (D, E) In contrast, the total estimated number of $\mathrm{BrdU}^{+} \mathrm{CC}^{+}$cells was significantly increased in $1 \mathrm{kBa}$-dn mice ( $\mathbf{D},{ }^{*} P<0.05$, Student's $t$-test) with a higher number of newly formed oligodendrocytes around the epicenter compared to those in $W T$ mice $\left(\mathbf{E}\right.$, two-way analysis of variance; ${ }^{*} P<0.05$ Bonferroni post-test). (F) Representative pictures of $\mathrm{BrdU}^{+} \mathrm{NG}^{+}$and $\mathrm{Brdu}^{+} \mathrm{CC}^{+}$cells showing co-labeling with the oligodendroglial lineage marker Olig2. (G, left) At this time point, the total number of mature oligodendrocyte $\left(\mathrm{CC}^{+}\right.$cells) in the injured spinal cord of I $\mathrm{kBa}$-dn mice was also significantly $\left({ }^{*} P<0.05\right.$, Student's $t$-test) higher than in WT mice. (G, right) Western blot quantification on mice with 6 weeks survival also showed a significant increase in the myelin protein PLP in IkBa-dn mice compared to WT mice $\left({ }^{*} P<0.05\right.$, Student's $t$-test) supporting increased oligodendrogenesis in IkBa-dn mice already at 6 weeks post-SCI. $\mathrm{N}=4$ animals per group. NG2, nerve/glial antigen 2 .

environment favorable for oligodendrogenesis (Figures 2 and 3). To explore oligodendrogenesis further, we focused on genes previously demonstrated to be important in cell proliferation and oligodendrogenesis such as Sox17 and Lingo-1 [24,25]. While not a specific indicator of oligodendrogenesis, we found that Ki67, a general marker of proliferation, was significantly elevated 3 days post-SCI in both WT and I $\mathrm{WB} \alpha-\mathrm{dn}$ mice relative to naïve animals but only in $\mathrm{I}_{\kappa} \mathrm{B} \alpha-\mathrm{dn}$ mice 6 weeks post-SCI (Figure 3A). Some possible sources for Ki67 expression, besides infiltrating immune cells, are also OPCs. Sox17, a transcription factor important in oligodendrocyte development [26], was significantly upregulated in IkB $\alpha-d n$ mice 6 weeks post-SCI (Figure 3B), while Lingo-1, a negative regulator of oligodendrogenesis [27], was significantly reduced in $\mathrm{I} \kappa \mathrm{B} \alpha-\mathrm{dn}$ mice at this time point (Figure 3F). These findings support the data presented in Figure 2 showing significantly increased numbers of $\mathrm{BrdU}^{+} \mathrm{CC}^{+}$oligodendrocytes, significantly increased numbers of $\mathrm{CC}^{+}$oligodendrocytes and significantly increased PLP levels in IKB $\alpha-d n$ mice, suggesting increased oligodendrogenesis in the IкB $\alpha-\mathrm{dn}$ mice compared to WT mice.

Inhibition of astroglial NF-KB results in an altered inflammatory state that is supportive of oligodendrogenesis after spinal cord injury

An inflammatory reaction following traumatic injury is necessary to contain the injury and clear debris, and

Table 1 Microarray data summary

\begin{tabular}{llll}
\hline Time post-SCI & $\begin{array}{l}\text { Total number } \\
\text { of differentially } \\
\text { expressed } \\
\text { genes }\end{array}$ & $\begin{array}{l}\text { Genes under } \\
\text { expressed in } \\
\text { GFAP-IKBa-dn } \\
\text { mice }\end{array}$ & $\begin{array}{l}\text { Genes over } \\
\text { expressed in } \\
\text { GFAP-IKBa-dn } \\
\text { mice }\end{array}$ \\
\hline Naive & 66 & $15(22.7 \%)$ & $51(77.3 \%)$ \\
$\mathbf{3}$ days & 35 & $3(8.6 \%)$ & $32(91.4 \%)$ \\
$\mathbf{3}$ weeks & 108 & $69(63.9 \%)$ & $39(36.1 \%)$ \\
$\mathbf{6}$ weeks & 994 & $596(60.0 \%)$ & $398(40.0 \%)$ \\
\hline
\end{tabular}

Number of differentially expressed genes between wild-type and GFAP-IKBa-dn mice at various time points following spinal cord injury $(\mathrm{SCl})$. Results are derived from the analysis of three biological replicates/time points. microglia - the resident macrophages of the central nervous system (CNS) - are rapidly activated following disturbances and secrete pro-inflammatory cytokines $[28,29]$. Different phenotypes of microglia have been identified [30] and even though often associated with neuroinflammatory processes, their role has been extended to maintenance and repair of the nervous tissue where they reside [31,32], some of them being supportive of remyelination [33,34]. Also, distinct subsets of macrophages have been shown to cause either toxicity or regeneration in the injured mouse spinal cord [35]. Since in the present study we found a significant increase in CD11b mRNA levels using qPCR in our IkB $\alpha-\mathrm{dn}$ mice compared to WT mice at 6 weeks

Table 2 Genes associated directly or indirectly with myelination

\begin{tabular}{|c|c|c|}
\hline \multirow[t]{2}{*}{ Gene name } & \multirow{2}{*}{$\begin{array}{l}\text { Accession } \\
\text { number }\end{array}$} & \multirow{2}{*}{$\begin{array}{l}\text { Fold change } \\
\text { GFAP-IKBa-dn mice } \\
\text { versus wild-type } \\
\text { mice at } 6 \text { weeks }\end{array}$} \\
\hline & & \\
\hline \multicolumn{3}{|c|}{ Chemokine-Chemokine receptors } \\
\hline $\mathrm{CxCl} 12$ & NM_013655 & +2.19 \\
\hline Cxcr4 & NM_009911 & +2.01 \\
\hline \multicolumn{3}{|c|}{ Transcription factors } \\
\hline Foxc2 & NM_013519 & +6.55 \\
\hline Sox 17 & NM_0011441 & +5.35 \\
\hline Tcf4 & NM_009333 & +2.24 \\
\hline \multicolumn{3}{|c|}{ Proliferation marker } \\
\hline mKi67 & X82786 & +2.43 \\
\hline \multicolumn{3}{|c|}{ Microglia/leukocytes } \\
\hline Itga1 (CD11b) & NM_176922 & +2.03 \\
\hline CD200r & NM_021325 & +2.49 \\
\hline TLR4 & NM_021297 & +2.38 \\
\hline \multicolumn{3}{|l|}{ Inhibitor } \\
\hline Lingo 1 & BC008626 & -2.07 \\
\hline \multicolumn{3}{|l|}{ Myelin } \\
\hline PMP2 & NM_001030305 & +2.33 \\
\hline
\end{tabular}



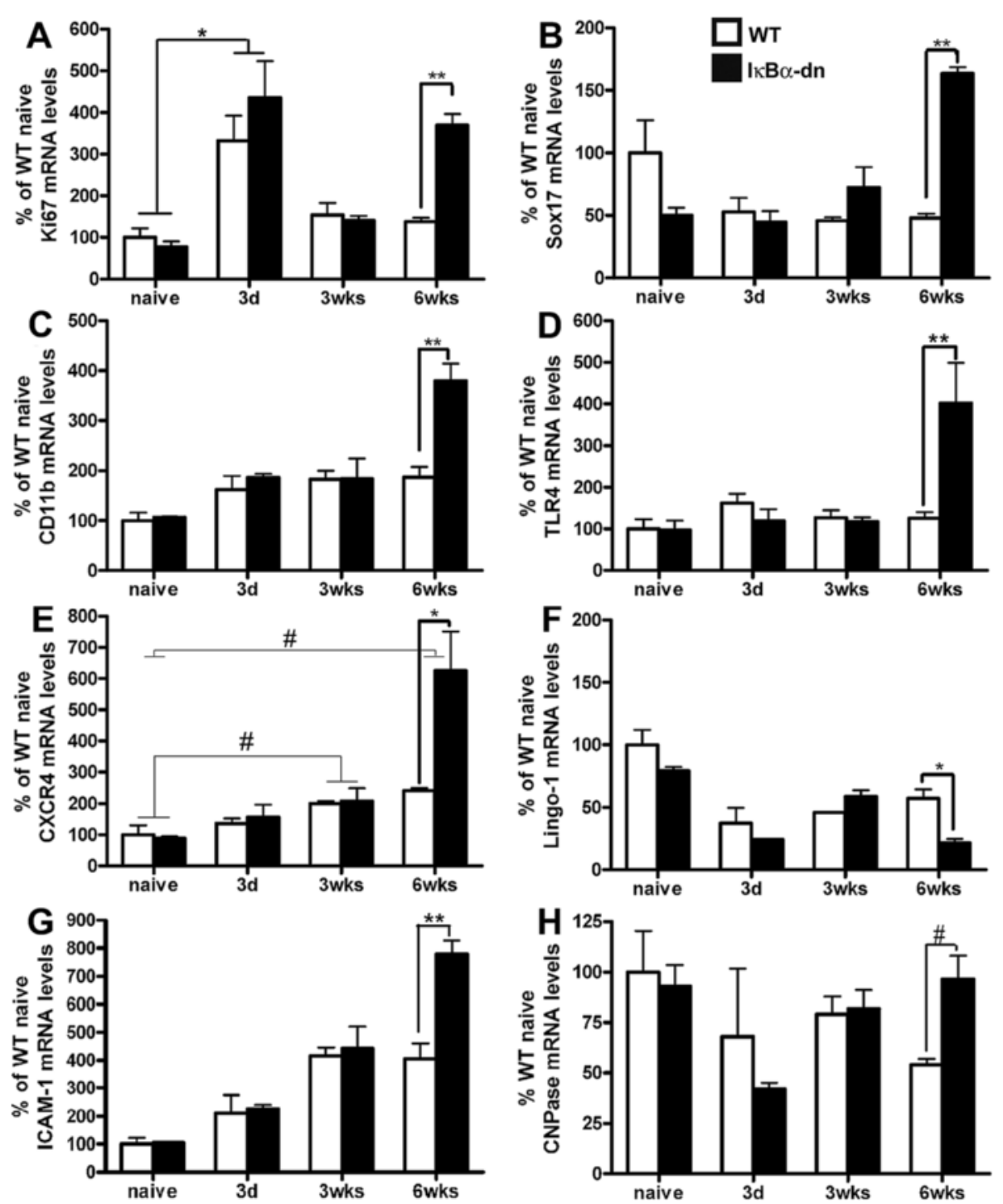

Figure 3 Quantitative real-time PCR was used to confirm a number of differentially regulated genes between wild-type (WT) and IKBa-dn mice. ${ }^{*} P<0.05,{ }^{*} P<0.01$, two-way analysis of variance followed by Bonferroni post tests; ${ }^{*} P<0.05, t$-test; $N=3$ animals per group. $3 \mathrm{~d}, 3$ days; 3 wks, 3 weeks; 6 wks, 6 weeks.

post-SCI (Figure 3C), we further estimated the total

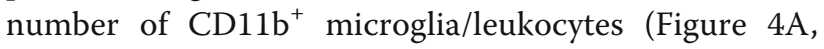
shown for naïve and 6 weeks). In naïve mice there were significantly more CD11b ${ }^{+}$cells in WT mice compared to IKB $\alpha$-dn mice $(P<0.05$, Figure 4B). However, counting $\mathrm{CD}_{11 \mathrm{~b}^{+}}$microglia/leukocytes in both IкB $\alpha$-dn and WT mice 3 days and 6 weeks after SCI did not show evidence of a difference in the total number of $\mathrm{CD} 11 \mathrm{~b}^{+}$cells between the two genotypes, even though the total number of $\mathrm{CD}_{11 \mathrm{~b}^{+}}$cells was significantly increased in both IKB $\alpha-\mathrm{dn}$ and WT mice 6 weeks after SCI compared to naïve mice $(P<0.001$, one-way ANOVA) (Figure $4 \mathrm{~A}, \mathrm{~B})$. These data suggest that the microglial numbers and leukocyte infiltration is similar between I $\mathrm{B} \alpha-\mathrm{dn}$ and WT mice but that the transcriptional regulation of $\mathrm{CD} 11 \mathrm{~b}$ mRNA levels and possibly the activation status of these cells 6 weeks after SCI are differently regulated in $\mathrm{I} \kappa \mathrm{B} \alpha-\mathrm{dn}$ mice compared to WT mice.

Since TLR4, a pattern recognition receptor important in innate immunity that has been shown to modulate myelination, astrogliosis and macrophage activation $[34,36]$, was found to be up-regulated in the microarray at 6 weeks post-injury in the IкB $\alpha$-dn mice, we confirmed by qPCR the significant increase in TLR4 mRNA in $\mathrm{I} K \mathrm{~B} \alpha-\mathrm{dn}$ mice (Figure 3D). We further examined the cellular expression of TLR4 in injured spinal cord tissue

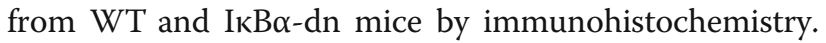
TLR4 immunoreactivity colocalized almost exclusively with $\mathrm{CD}_{11 \mathrm{~b}^{+}}$microglia/leukocytes in both WT and 

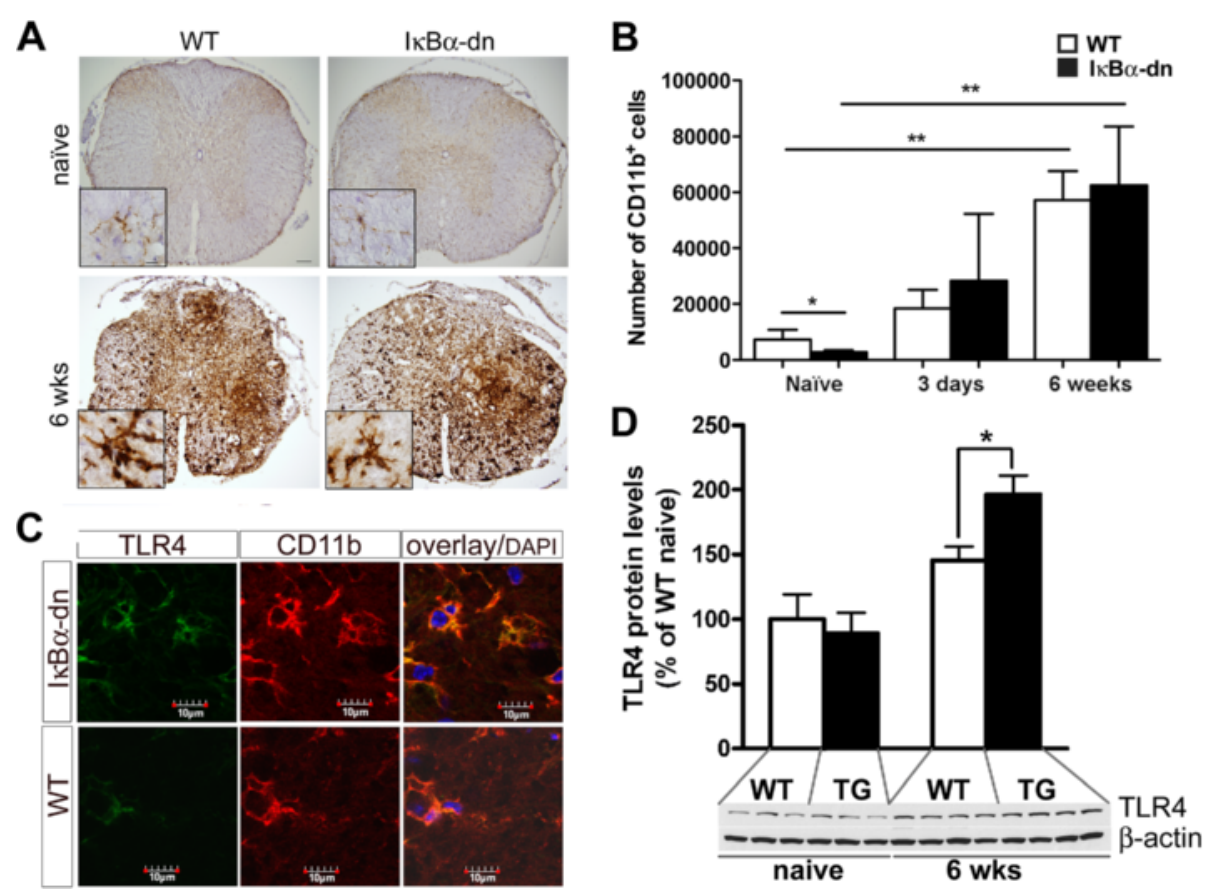

Figure 4 Quantification of microglia/leukocytes in the naïve, 3 days, and 6 weeks injured spinal cord. (A) Representative immunohistochemical staining for CD11b in naïve wild-type (WT) and IkBa-dn mice and 6 weeks (wks) following spinal cord injury (SCI). (B) The total number of $\mathrm{CD}_{11} \mathrm{~b}^{+}$cells were significantly increased in naïve IKBa-dn mice compared to WT mice and significantly increased 6 weeks after $\mathrm{SCl}$ in both IKBa-dn and WT mice. Each bar represents the average cell count \pm SEM. ${ }^{*} P<0.05$, ${ }^{*} P<0.01, N=4$ to 9 animals per group. (C) Representative photomicrographs of immunohistochemical stainings for toll-like receptor 4 (TLR4) in the injured spinal cord white matter of WT and IkBa-dn mice, showing a robust staining on CD11 $\mathrm{b}^{+}$microglia/leukocytes from the chronically injured IkBa-dn mice.

(D) Western blot quantification showing a significant increase in TLR4 in IkBa-dn mice (TG) compared to WT mice 6 weeks after SCI. N = 3 to 4 animals per group, ${ }^{*} P<0.05$. DAPI, 4',6-diamidino-2-phenylindole.

I $\mathrm{B} \alpha \alpha-\mathrm{dn}$ mice and showed stronger immunoreactivity in the injured spinal cord of the IkB $\alpha$-dn mice compared to WT (Figure 4C), suggesting a difference in the state of activation of microglia/leukocytes between the two genotypes. This was further supported by the finding of a significant increase in TLR4 protein levels in IKB $\alpha-\mathrm{dn}$ mice 6 weeks post-SCI compared to WT LM $(P<0.05$, Figure 4D).

\section{CXCR4 expression is increased on oligodendrocytes following spinal cord injury}

Chemokines and their receptors are also known to be important regulators of inflammation and repair processes following CNS injury [37]. Signaling through the alpha chemokine receptor CXCR4 is required for migration of neuronal precursors, axon guidance/pathfinding, neurite growth and maintenance of neuronal progenitor cells as well as oligodendrocyte progenitors and remyelination [38-42]. Furthermore, CXCL12 signaling through CXCR4 enhances the infiltration of monocytes and lymphocytes in different inflammation models $[43,44]$. In line with these findings, CXCR4 mRNA levels were significantly upregulated in IKB $\alpha-d n$ and WT mice at 3 and 6 weeks after SCI compared to naïve mice (Figure 3E).
Furthermore, at 6 weeks post-SCI, IkB $\alpha$-dn mice displayed significantly higher CXCR4 mRNA levels compared to injured WT mice (Figure 3E). This was further confirmed using western blotting and immunohistochemical expression analysis of CXCR4 (Figure 5A,B). In line with qPCR analysis, CXCR4 protein levels were significantly upregulated in $\mathrm{I} \kappa \mathrm{B} \alpha-\mathrm{dn}$ mice 6 weeks after SCI compared to naïve mice, $(P=0.013)$ and compared to WT mice with 6 weeks survival $(P=0.038$, Figure 5A). CXCR4 was expressed in $\mathrm{CC}^{+}$oligodendrocytes both in $\mathrm{I} \kappa \mathrm{B} \alpha-\mathrm{dn}$ and WT mice with increased expression in IkB $\alpha$-dn mice (Figure 5B, shown for 6 weeks). CXCR4 was also found to be expressed in some $\mathrm{NG}^{+}$-cells 6 weeks after SCI (Figure 5C).

Since the transcription factor Foxc2 is important in CXCR4 regulation [45], we further compared Foxc2 expression at this time point using western blotting. In line with the findings of significantly increased protein CXCR4 levels in IкB $\alpha$-dn compared to WT mice, Foxc2 protein levels were also significantly upregulated 6 weeks post-SCI in IkB $\alpha$-dn compared to WT mice (Figure 5D).

Furthermore, CXCR7 has been implicated in the pathophysiology of demyelination and axonal injury in EAE where antagonism of CXCR7 promotes functional 


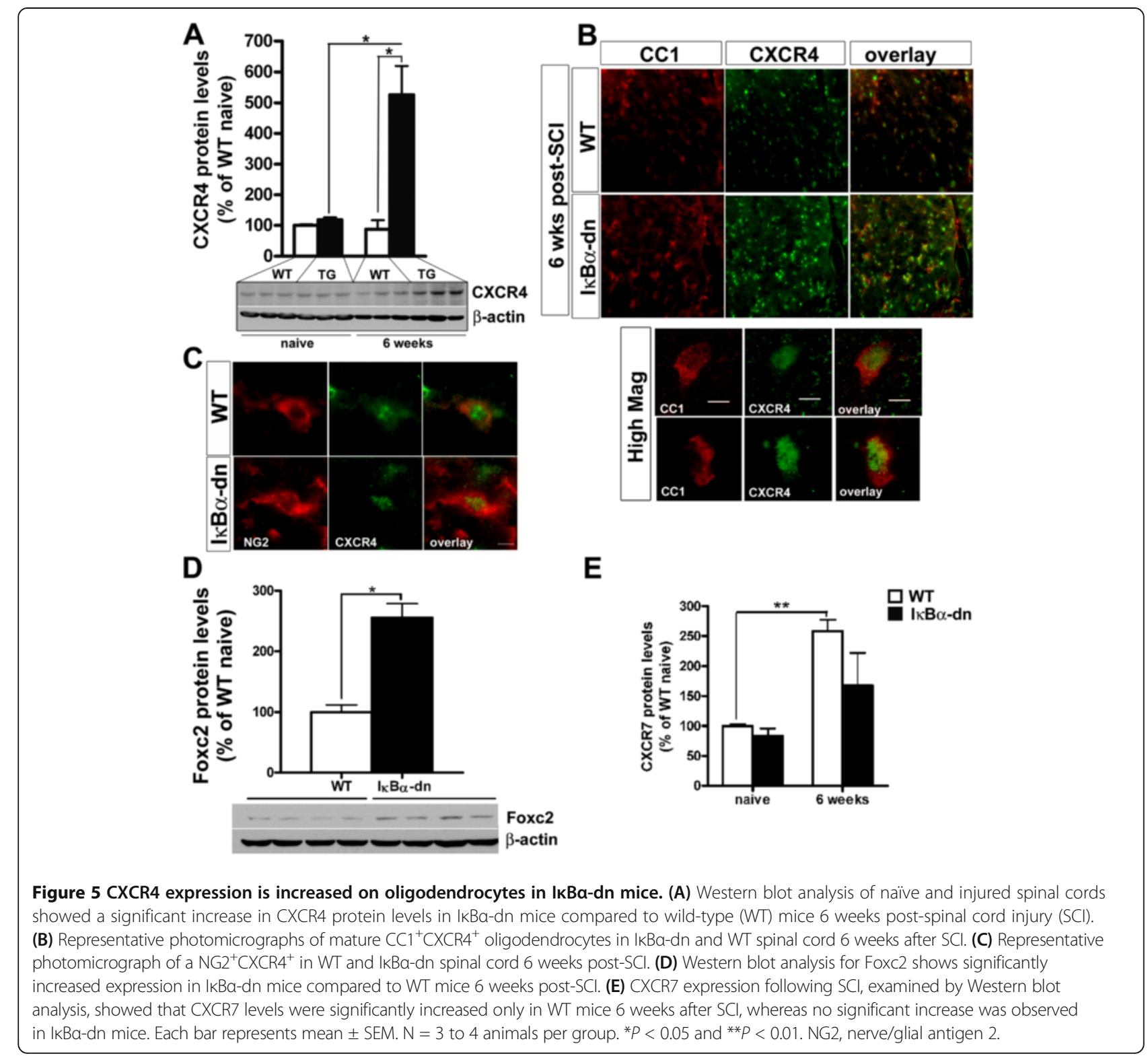

recovery and reduces axonal injury [46]. CXCR7 was not in the microarray analysis but based upon the role it plays in EAE and our present results on CXCR4, we investigated CXCR7 protein expression following SCI (Figure 5E). We detected a significant increase in CXCR7 expression 6 weeks post-SCI in WT mice but not in IKB $\alpha-\mathrm{dn}$ mice compared to naïve spinal cords (Figure 5E), suggesting that CXCR7 expression is significantly reduced by inhibition of NF- $\mathrm{kB}$ in astrocytes.

\section{IKBa-dn mice displayed increased TNFR2 expression} compared to wild-type mice after spinal cord injury TNF signaling through TNFR2 has been shown to promote proliferation of OPCs and remyelination [47] and recently, using XPro1595 a specific inhibitor for soluble
TNF in EAE, we demonstrated a beneficial role of TNFR2 signaling on functional outcome [48]. Based upon these data, we sought to determine what effect inhibiting astroglial NF- $\kappa B$ would have on TNFR2 expression following SCI. As shown in Figure 6A, there was significantly increased TNFR2 protein expression in I $\mathrm{B} B \alpha-\mathrm{dn}$ mice 6 weeks after injury compared to injured WT mice (Figure 6A), due to a decrease in protein levels in WT mice that did not occur in IKB $\alpha-\mathrm{dn}$ mice. These findings were supported by immunohistochemical stainings showing increased levels of TNFR2 in WT mice compared to IкB $\alpha$-dn mice, whereas the levels in naïve spinal cords appeared similar (Figure 6B). In naïve spinal cords, TNFR2 was expressed primarily by oligodendrocytes (Figure 6B) whereas 6 weeks after SCI, TNFR2 


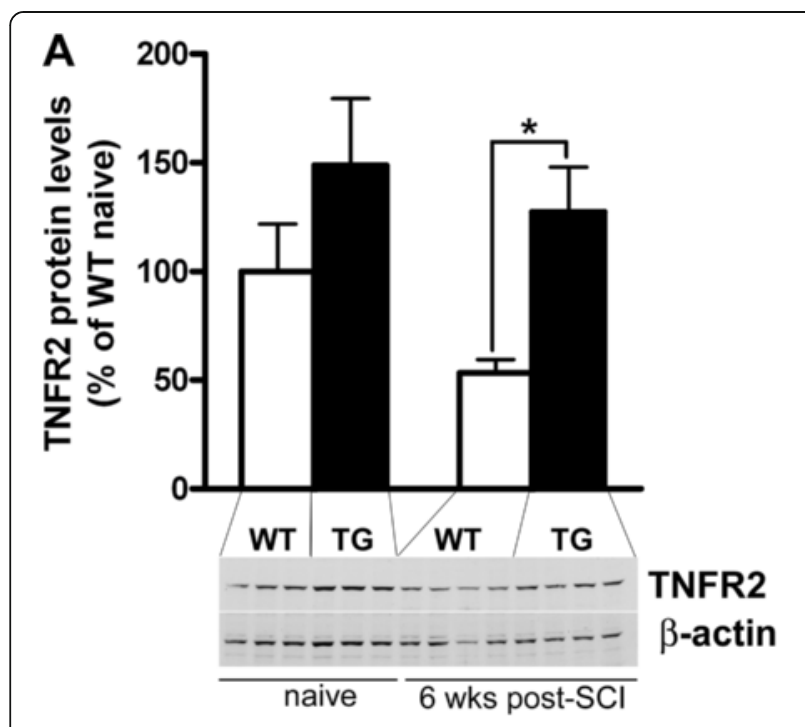

B

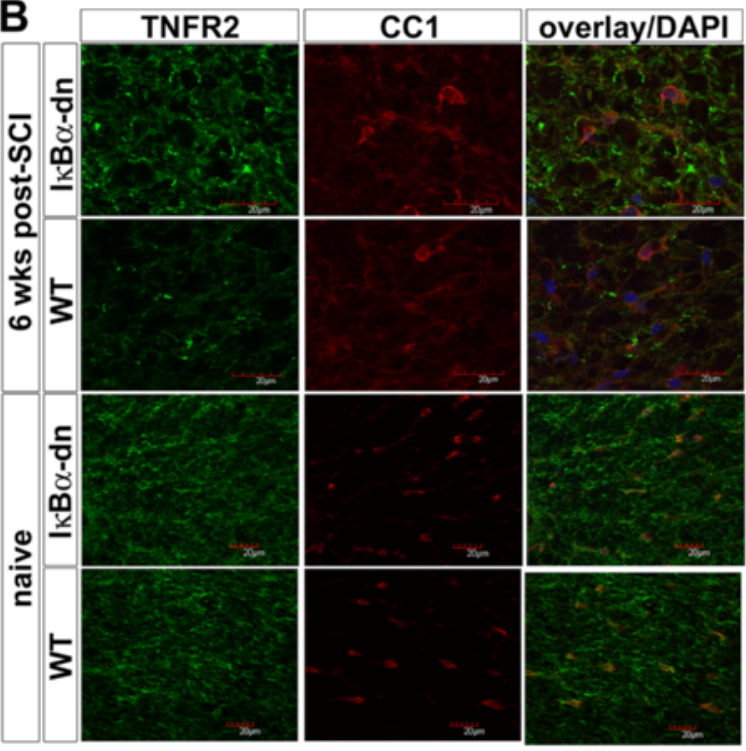

Figure 6 TNFR2 expression is increased in the IKBa-dn injured spinal cord compared to wild-type 6 weeks post-spinal cord injury. (A) Quantification of TNFR2 protein expression levels in the injured spinal cord of wild-type (WT) and IkBa-dn mice showing significantly less protein in WT mice 6 weeks after spinal cord injury (SCl) compared to $\mathrm{kBa}-\mathrm{dn}$ mice. Each bar represents the mean $\pm \mathrm{SEM}$. ${ }^{*} P<0.05$. $N=3$ to 4 animals per group. (B) Representative confocal images of mature $\mathrm{CC} 1$ oligodendrocytes and TNFR2 expression in naïve and injured spinal cord from WT and IKBa-dn mice, showing that a subset of TNFR2 ${ }^{+}$cells co-localizes with $\mathrm{CC}^{+}$oligodendrocytes.

expression was also expressed in other types of cells (Figure 6B), probably microglia and infiltrating macrophages, as shown previously for other CNS injuries [49]. These data, along with our previous studies, suggest that enhanced oligodendrogenesis could be due in part to the sustained expression of TNFR2 in I $\mathrm{B} \alpha-\mathrm{dn}$ mice following injury.
Collectively, our data suggest that sustained expression of TNFR2 in IkB $\alpha-\mathrm{dn}$ mice enhances the expression of CXCR4 and thereby promotes an environment supportive of oligodendrogenesis and remyelination. Furthermore, CXCR7 is expressed on astrocytes and signals through NF- $\mathrm{kB}$ suggesting that the reduced neuropathology in our IkB $\alpha-d n$ mice could be due to impaired CXCR7 expression and signaling in these mice.

\section{Discussion}

In a previous study, we showed that mice lacking functional NF- $\mathrm{B}$ signaling in astrocytes (GFAP-IkB $\alpha-\mathrm{dn}$ transgenic mice) recover better following moderate spinal cord contusion, with a significant improvement in locomotor function that correlates with a smaller lesion area and a larger area of white matter preservation compared to injured WT LM [12]. Since the mice were generated several years ago, we confirmed that they still retained the same phenotype following SCI and found that the GFAP-Ikb $\alpha-d n$ mice still did perform significantly better than the WT mice on the Basso Mouse Scale following moderate SCI, supported by a smaller lesion size and more myelin 6 weeks post-SCI. The larger white matter volume in the I $\mathrm{B} B \alpha-\mathrm{dn}$ transgenic mice could be due to sparing of oligodendrocytes from cell death and/or to an increase in oligodendrogenesis. In the present paper, we demonstrate that there is indeed an increase in oligodendrogenesis in the IkB $\alpha$-dn transgenic mice compared to the WT LM 6 to 7 weeks postSCI. In the naïve mice we did not find any differences in the number of oligodendrocytes or the amount of myelin between WT and transgenic mice suggesting that blocking NF- $\mathrm{kB}$ signaling in astrocytes under naïve conditions does not affect myelination. However, following SCI we found a large increase in the number of newly formed $\mathrm{BrdU}^{+} / \mathrm{CC}^{+}$oligodendrocytes, suggesting that astroglial NF- $\mathrm{kB}$ directly or indirectly affects the differentiation of OPC into mature, myelinating oligodendrocytes. In fact, a recent study showed that reactive astrocytes from the injured spinal cord can inhibit oligodendrocyte differentiation in vitro [11]. Many others have also shown that astrocytes can directly modulate myelination in vitro via the release of a number of secreted factors, depending on culture conditions $[7,10]$. In our study, it is so far unknown whether the decreased expression of a NF- $\mathrm{kB}$-regulated gene has a direct effect on oligodendrocyte maturation or an indirect effect through other cells such as microglia and/or infiltrating macrophages. Indeed, factors secreted by macrophages from the injured spinal cord have been shown to inhibit growth of $\mathrm{NG}^{+}$cells in vitro [50]. When we examined the distribution of the $\mathrm{BrdU}^{+} / \mathrm{CC}^{+}$cells, we found numerous double immunolabeled cells located around the

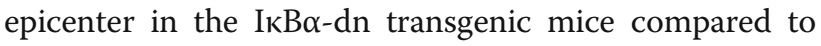


the WT LM mice, suggesting that while the lesion epicenter in the WT mice is inhibitory for oligodendrocyte differentiation, the epicenter environment in the transgenic mice is more permissive and may allow for a better survival of newly generated oligodendrocytes. To gain insight into the molecular mechanisms underlying increased oligodendrogenesis, we performed a microarray analysis on naïve and injured spinal cords at 3 days, 3 and 6 weeks post-SCI and found the largest number of differentially regulated genes between WT and GFAP$\mathrm{I} \kappa \mathrm{B} \alpha-\mathrm{dn}$ mice at the more chronic time point. Since analysis of the set of genes pointed to differences in the inflammatory response with upregulation of genes such as CD11b, TLR4, CXCL12, and CXCR4 in IkB $\alpha$-dn mice compared to the WT mice, we sought to determine whether differences in the number of microglia/leukocytes could account for the observed differences. Even though we did not find any differences in terms of total number of $\mathrm{CD}_{11 \mathrm{~b}^{+}}$cells between WT and GFAP-IKB $\alpha-\mathrm{dn}$ mice 6 weeks following SCI, we found differences in TLR4 levels, with the microglia/leukocytes from the transgenic mice showing enhanced immunoreactivity compared to the WT mice. Inflammatory reactions are important in stimulating recruitment of OPCs to demyelinating areas and in the remyelination process itself [34,51,52]. Recently, diverse microglia/macrophage phenotypes have been identified through their expression of specific sets of genes, making them either neuroprotective and reparative or toxic to the neural cells $[20,33,35]$. Our data suggest that inhibiting astroglial NF- $\mathrm{KB}$ affects the activation status of microglia/leukocytes rendering them more supportive for remyelination. In fact the role of astrocytes in modulating microglia has been highlighted in a study where astrocytes from glioblastoma have been shown to suppress microglial function [53]. It appears that the number of astrocytes may also be an important factor in the regulation of microglial function. However, we did not find any significant difference in the number of astrocytes in the spinal cord from naïve WT and $\mathrm{I} \kappa \mathrm{B} \alpha-\mathrm{dn}$ transgenic mice (Additional file 1).

Chemokines are essential for trafficking of leukocytes in both physiological and pathological conditions [54]. CXCL12, also known as stromal-derived growth factor 1 or SDF-1, can act through two G-coupled receptors, CXCR4 and CXCR7. CXCL12 and its receptor CXCR4 play multiple roles both in the immune and nervous systems. CXCL12 is a highly efficacious chemoattractant for lymphocytes and monocytes but not neutrophils [44]. CXCR4 signaling is required for the migration of neuronal precursors, axon guidance/pathfinding and maintenance of neural progenitor cells. In the mature CNS, CXCL12 modulates neurotransmission, neurotoxicity and neuroglial interactions. It activates NF- $\mathrm{kB}$, stimulates the production of chemokines and cytokines and induces cell death in primary astrocytes [55]. CXCL12 stimulates neurite growth on inhibitory CNS myelin [40]. Regarding the role of CXCL12 in remyelination there are some divergent results as whether it promotes oligodendrocyte maturation through its receptor CXCR4 [56] or CXCR7 [57]. These apparent discrepancies may be due to the injury paradigm being a drug-induced demyelination of the corpus callosum in the study by Gottle and colleagues [57] and a myelin oligodendrocyte glycoprotein-induced EAE model in the study by Patel and colleagues [56]. In our chronically spinal cord injured mouse model, we observed a strong induction of CXCR4 on oligodendrocytes especially in $\mathrm{I} k \mathrm{~B} \alpha-\mathrm{dn}$ mice compared to WT, which is in stark contrast with the study from Gottle and colleagues [57] where they did not observe any expression of CXCR4 on oligodendroglial cells in both healthy and diseased spinal cord. The pathophysiology of SCI and EAE is very distinct, which could explain some of the differences observed in models of SCI and EAE. The pattern of expression of CXCR4 appeared mostly nuclear although we also found cytoplamic/membrane staining as well. Nuclear localization of CXCR4 has been reported following binding to CXCL12 and its function in the nucleus is still speculative [58]. As in the study by Patel and colleagues [56], we found CXCR4 expressed by some $\mathrm{NG}^{+}$cells both in WT and IкB $\alpha-\mathrm{dn}$ mice. Due to the expression of CXCR4 on NG2 ${ }^{+}$cells and in oligodendrocytes, this would suggest a role in both myelination and oligodendrocyte survival. Regarding CXCR7, we observed an induction at 6 weeks in the injured WT mice, but not in the IkB $\alpha-d n$ mice while antagonism to CXCR7 has been reported to promote oligodendrocyte maturation [57] and to prevent axonal injury [46] in two different models of EAE.

TNF is a cytokine that plays different roles depending on the receptor it engages, being either TNFR1 or TNFR2. Originally viewed as a pro-inflammatory cytokine, knockout studies have demonstrated that TNF does not only have deleterious effects following CNS trauma or disease $[29,59]$, but is also involved in the repair phase specifically through its cognate TNFR2 (p75) receptor [47]. Recently, our laboratory has demonstrated, using a specific inhibitor of soluble TNF, that signaling of membrane-bound TNF through its receptor TNFR2 was associated with axonal preservation and improved myelin compaction following EAE [48]. Furthermore a recent study by Patel and colleagues showed that TNFR2 was required for OPC proliferation and differentiation in a drug-induced demyelination model of the corpus callosum [60]. Therefore, we sought to determine whether TNFR2 expression was altered following SCI. Our data showed that TNFR2 expression was reduced 6 weeks following SCI in WT mice but 
was maintained at levels similar to the naïve conditions in our transgenic mice suggesting that signaling through TNFR2 on oligodendrocytes may have a positive effect on myelination as seen in EAE.

The fact that in the present study we observed dramatic gene changes at the more chronic time point may be explained by the biphasic infiltration of leukocytes in mice following SCI with a late peak occurring in the chronic phase 42 days after injury [61-63].

\section{Conclusion}

In conclusion, our data demonstrate that one of the beneficial roles of blocking NF- $\mathrm{KB}$ in astrocytes is to promote oligodendrogenesis through alteration of the inflammatory environment at and around the lesion site. In particular, our data suggest that astrocytes may be modulating microglial/leukocyte activation towards a phenotype that is supportive of oligodendrogenesis and repair.

\section{Additional file}

\begin{abstract}
Additional file 1: Inhibition of astroglial NF-KB does not affect the number of astrocytes in the naïve, murine adult spinal cord.

(A) Representative immunostained spinal cord cross sections from naïve wild-type (WT) and IkBa-dn transgenic (TG) mice. Astrocytes were immunostained using a polyclonal rabbit anti-GFAP (DAKO, 1:1000) and an Alexa594 anti-rabbit secondary antibody (Molecular Probe, 1:500). Hoechst was used to label the nuclei. Scale bar: $100 \mu \mathrm{m}$. (B) High magnification of astrocytes in the white matter spinal cord of WT and IkBa-dn TG mice. Scale bar: $20 \mu \mathrm{m}$. (C) Estimation of the number of astrocytes in the white matter and grey matter of a 1-mm long spinal cord segment in the thoracic region of naïve WT and IkBa-dn mice using unbiased stereology (grid size $120 \mu \mathrm{m} \times 120 \mu \mathrm{m}$ and probe size $40 \mu \mathrm{m} \times$ $40 \mu \mathrm{m}$ ) showed no difference between genotypes (mean \pm SEM, $N=3$ per group). (D) Glial fibrillary acidic protein (GFAP) gene expression level in the spinal cord was assessed by real-time PCR. Data were normalized to $\beta$-actin and expressed as percent of $W T$ (mean \pm SEM, $N=5$ per group).
\end{abstract}

\section{Abbreviations \\ ANOVA: Analysis of variance; APC: Adenomatous polyposis coli; asf: Area sampling fraction; BrdU: Bromodeoxyuridine; BSA: Bovine serum albumin; CNS: Central nervous system; DAPI: 4',6-diamidino-2-phenylindole; EAE: Experimental autoimmune encephalomyelitis; FDR: False discovery rate; GFAP: Glial fibrillary acidic protein; H\&E: Hmatoxylin and eosin; Ig: Immunoglobulin; i.p.: Intraperitoneally; LM: Littermates; NG2: Nerve/glial antigen 2; NGS: Normal goat serum; NF-kB: Nuclear factor-kappa B; OPC: Oligodendrocyte precursor cell; PBS: Phosphate buffered saline; PCR: Polymerase chain reaction; PFA: Paraformaldehyde; PLP: Proteolipid protein; RT-PCR: Reverse transcriptase-polymerase chain reaction; S.C.: Cubcutaneously; SCI: Spinal cord injury; ssf: Sampling section fraction; TBS-T: Tris buffered saline-triton; TLR: Toll-like receptor; TNF: Tumor necrosis factor; TNFR: Tumor necrosis factor receptor; tsf: Thickness sampling fraction; WT: Wild-type.}

\section{Competing interests}

The authors declare that they have no competing interests.

\section{Authors' contributions}

VBR participated in study design, performed the BrdU experiments, performed the immunohistochemical, biochemical and $\mathrm{QPCR}$ experiments and wrote the manuscript. KLL participated in study design, performed assessment of the mice, the microglia analysis, and participated in writing the manuscript. JR performed surgeries. LN performed the microarray experiment and analysis. SK participated in mouse behavioral assessment. J performed some oligodendrocyte counting. DGE performed the microglia analysis. BF participated in the microglia analysis, lesion volume and white matter quantification. DMM conceived the oligodendrogenesis study. JRB conceived the study and helped draft the paper. All authors read and approved the final manuscript.

\section{Acknowledgements}

This work was supported by NIH grants NS051709-06 (JRB) and The Danish MRC and the Carlsberg Foundation (KLL). The authors acknowledge the technical assistance provided by technicians Karen Rich, Inge Holst Nielsen, Dorte Lyholmer and Louise Lykkemark.

\section{Author details}

${ }^{1}$ The Miami Project to Cure Paralysis, University of Miami, Miami FL 33136, USA. ${ }^{2}$ Department of Neurobiology Research, Institute of Molecular Medicine, University of Southern Denmark, 5000, Odense, C, Denmark. ${ }^{3}$ Department of Molecular and Cellular Medicine, Miller School of Medicine, University of Miami, Miami FL 33136, USA. ${ }^{4}$ Department of Neuroscience, The Center for Brain and Spinal Cord Repair, The Ohio State University, 795 12th Avenue, Columbus $\mathrm{OH}$ 43210, USA.

Received: 4 March 2013 Accepted: 12 July 2013

Published: 23 July 2013

\section{References}

1. Donnelly DJ, Popovich PG: Inflammation and its role in neuroprotection, axonal regeneration and functional recovery after spinal cord injury. Exp Neurol 2008, 209:378-388.

2. Tripathi R, McTigue DM: Prominent oligodendrocyte genesis along the border of spinal contusion lesions. Glia 2007, 55:698-711.

3. Franklin RJ, Ffrench-Constant C: Remyelination in the CNS: from biology to therapy. Nat Rev Neurosci 2008, 9:839-855.

4. Kremer D, Aktas O, Hartung HP, Kury P: The complex world of oligodendroglial differentiation inhibitors. Ann Neurol 2011, 69:602-618.

5. Kotter MR, Li WW, Zhao C, Franklin RJ: Myelin impairs CNS remyelination by inhibiting oligodendrocyte precursor cell differentiation. J Neurosci 2006, 26:328-332.

6. Brambilla R, Persaud T, Hu X, Karmally S, Shestopalov VI, Dvoriantchikova G, Ivanov D, Nathanson L, Barnum SR, Bethea JR: Transgenic inhibition of astroglial NF-kappa B improves functional outcome in experimental autoimmune encephalomyelitis by suppressing chronic central nervous system inflammation. J Immunol 2009, 182:2628-2640.

7. Moore CS, Abdullah SL, Brown A, Arulpragasam A, Crocker SJ: How factors secreted from astrocytes impact myelin repair. J Neurosci Res 2011, 89:13-21.

8. Moore CS, Milner R, Nishiyama A, Frausto RF, Serwanski DR, Pagarigan RR, Whitton JL, Miller RH, Crocker SJ: Astrocytic tissue inhibitor of metalloproteinase-1 (TIMP-1) promotes oligodendrocyte differentiation and enhances CNS myelination. J Neurosci 2011, 31:6247-6254.

9. Khorooshi R, Babcock AA, Owens T: NF-kappaB-driven STAT2 and CCL2 expression in astrocytes in response to brain injury. J Immunol 2008, 181:7284-7291.

10. Nash B, Thomson CE, Linington C, Arthur AT, McClure JD, McBride MW, Barnett SC: Functional duality of astrocytes in myelination. J Neurosci 2011, 31:13028-13038.

11. Wang Y, Cheng X, He Q, Zheng Y, Kim DH, Whittemore SR, Cao QL: Astrocytes from the contused spinal cord inhibit oligodendrocyte differentiation of adult oligodendrocyte precursor cells by increasing the expression of bone morphogenetic proteins. J Neurosci 2011, 31:6053-6058

12. Brambilla R, Bracchi-Ricard V, Hu WH, Frydel B, Bramwell A, Karmally S, Green EJ, Bethea JR: Inhibition of astroglial nuclear factor kappaB reduces inflammation and improves functional recovery after spinal cord injury. J Exp Med 2005, 202:145-156.

13. Brambilla R, Hurtado A, Persaud T, Esham K, Pearse DD, Oudega M, Bethea JR: Transgenic inhibition of astroglial NF-kappa B leads to increased axonal sparing and sprouting following spinal cord injury. J Neurochem 2009, 110:765-778. 
14. Lambertsen KL, Gregersen R, Drojdahl N, Owens T, Finsen B: A specific a sensitive method for visualization of tumor necrosis factor in the murine central nervous system. Brain Res Brain Res Protoc 2001, 7:175-191.

15. Lambertsen $\mathrm{KL}$, Gregersen $\mathrm{R}$, Finsen $\mathrm{B}$ : Microglial-macrophage synthesis of tumor necrosis factor after focal cerebral ischemia in mice is strain dependent. J Cereb Blood Flow Metab 2002, 22:785-797.

16. West MJ, Ostergaard K, Andreassen OA, Finsen B: Estimation of the number of somatostatin neurons in the striatum: an in situ hybridization study using the optical fractionator method. J Comp Neurol 1996, 370:11-22.

17. Smyth GK, Michaud J, Scott HS: Use of within-array replicate spots for assessing differential expression in microarray experiments. Bioinformatics 2005, 21:2067-2075.

18. Smyth GK: Linear models and empirical bayes methods for assessing differential expression in microarray experiments. Stat Appl Genet Mol Biol 2004, 3:3.

19. Smyth GK, Speed T: Normalization of cDNA microarray data Methods 2003, 31:265-273.

20. Draghici S, Khatri P, Tarca AL, Amin K, Done A, Voichita C, Georgescu C, Romero R: A systems biology approach for pathway level analysis. Genome Res 2007, 17:1537-1545.

21. Zhang B, Kirov S, Snoddy J: WebGestalt: an integrated system for exploring gene sets in various biological contexts. Nucleic Acids Res 2005, 33:W741-W748.

22. Basso DM, Fisher LC, Anderson AJ, Jakeman LB, McTigue DM, Popovich PG: Basso Mouse Scale for locomotion detects differences in recovery after spinal cord injury in five common mouse strains. J Neurotrauma 2006, 23:635-659.

23. Nishiyama A, Komitova M, Suzuki R, Zhu X: Polydendrocytes (NG2 cells): multifunctional cells with lineage plasticity. Nat Rev Neurosci 2009, 10:9-22.

24. Mi S, Hu B, Hahm K, Luo Y, Kam Hui ES, Yuan Q, Wong WM, Wang L, Su H, Chu TH, Guo J, Zhang W, So KF, Pepinsky B, Shao Z, Graff C, Garber E, Jung V, Wu EX, Wu W: LINGO-1 antagonist promotes spinal cord remyelination and axonal integrity in MOG-induced experimental autoimmune encephalomyelitis. Nat Med 2007, 13:1228-1233.

25. Chew $L$, Shen W, Ming X, Senatorov W Jr, Chen HL, Cheng Y, Hong E, Knoblach S, Gallo V: SRY-box containing gene 17 regulates the Wnt/betacatenin signaling pathway in oligodendrocyte progenitor cells. J Neurosci 2011, 31:13921-13935.

26. Sohn J, Natale J, Chew $\sqcup$, Belachew S, Cheng Y, Aguirre A, Lytle J, NaitOumesmar B, Kerninon C, Kanai-Azuma M, Kanai Y, Gallo V: Identification of Sox17 as a transcription factor that regulates oligodendrocyte development. J Neurosci 2006, 26:9722-9735.

27. Mi S, Miller RH, Lee X, Scott ML, Shulag-Morskaya S, Shao Z, Chang J, Thill G, Levesque M, Zhang M, Hession C, Sah D, Trapp B, He Z, Jung V, McCoy JM, Pepinsky RB: LINGO-1 negatively regulates myelination by oligodendrocytes. Nat Neurosci 2005, 8:745-751.

28. Clausen BH, Lambertsen $\mathrm{KL}$, Meldgaard M, Finsen B: A quantitative in situ hybridization and polymerase chain reaction study of microglialmacrophage expression of interleukin-1beta mRNA following permanent middle cerebral artery occlusion in mice. Neuroscience 2005, 132:879-892.

29. Lambertsen KL, Clausen BH, Babcock AA, Gregersen R, Fenger C, Nielsen $\mathrm{HH}$, Haugaard LS, Wirenfeldt M, Nielsen M, Dagnaes-Hansen F, Bluethmann H, Faergeman NJ, Meldgaard M, Deierborg T, Finsen B: Microglia protect neurons against ischemia by synthesis of tumor necrosis factor. J Neurosci 2009, 29:1319-1330.

30. Clausen BH, Lambertsen KL, Babcock AA, Holm TH, Dagnaes-Hansen F, Finsen B: Interleukin-1beta and tumor necrosis factor-alpha are expressed by different subsets of microglia and macrophages after ischemic stroke in mice. J Neuroinflammation 2008, 5:46.

31. Glezer I, Lapointe A, Rivest S: Innate immunity triggers oligodendrocyte progenitor reactivity and confines damages to brain injuries. FASEB $J$ 2006, 20:750-752.

32. Loane DJ, Byrnes KR: Role of microglia in neurotrauma. Neurotherapeutics 2010, 7:366-377.

33. Olah M, Amor S, Brouwer N, Vinet J, Eggen B, Biber K, Boddeke HW: Identification of a microglia phenotype supportive of remyelination. Glia 2011, 60:306-321.

34. Schonberg DL, Popovich PG, McTigue DM: Oligodendrocyte generation is differentially influenced by toll-like receptor (TLR) 2 and TLR4-mediated intraspinal macrophage activation. J Neuropathol Exp Neurol 2007, 66:1124-1135

35. Kigerl KA, Gensel JC, Ankeny DP, Alexander JK, Donnelly DJ, Popovich PG: Identification of two distinct macrophage subsets with divergent effects causing either neurotoxicity or regeneration in the injured mouse spinal cord. J Neurosci 2009, 29:13435-13444.

36. Kigerl KA, Lai W, Rivest S, Hart RP, Satoskar AR, Popovich PG: Toll-like receptor (TLR)-2 and TLR-4 regulate inflammation, gliosis, and myelin sparing after spinal cord injury. J Neurochem 2007, 102:37-50.

37. Bajetto A, Bonavia R, Barbero S, Florio T, Schettini G: Chemokines and their receptors in the central nervous system. Front Neuroendocrinol 2001, 22:147-184.

38. Dziembowska M, Tham TN, Lau P, Vitry S, Lazarini F, Dubois-Dalcq M: A role for CXCR4 signaling in survival and migration of neural and oligodendrocyte precursors. Glia 2005, 50:258-269.

39. Li M, Chang CJ, Lathia JD, Wang L, Pacenta HL, Cotleur A, Ransohoff RM: Chemokine receptor CXCR4 signaling modulates the growth factorinduced cell cycle of self-renewing and multipotent neural progenitor cells. Glia 2011, 59:108-118.

40. Opatz J, Kury P, Schiwy N, Jarve A, Estrada V, Brazda N, Bosse F, Muller HW: SDF-1 stimulates neurite growth on inhibitory CNS myelin. Mol Cell Neurosci 2009, 40:293-300.

41. Banisadr G, Frederick TJ, Freitag C, Ren D, Jung H, Miller SD, Miller RJ: The role of CXCR4 signaling in the migration of transplanted oligodendrocyte progenitors into the cerebral white matter. Neurobiol Dis 2011, 44:19-27.

42. Carbajal KS, Miranda JL, Tsukamoto MR, Lane TE: CXCR4 signaling regulates remyelination by endogenous oligodendrocyte progenitor cells in a viral model of demyelination. Glia 2011, 59:1813-1821.

43. Petty JM, Sueblinvong V, Lenox CC, Jones CC, Cosgrove GP, Cool CD, Rai PR, Brown KK, Weiss DJ, Poynter ME, Suratt BT: Pulmonary stromal-derived factor-1 expression and effect on neutrophil recruitment during acute lung injury. J Immunol 2007, 178:8148-8157.

44. Bleul CC, Fuhlbrigge RC, Casasnovas JM, Aiuti A, Springer TA: A highly efficacious lymphocyte chemoattractant, stromal cell-derived factor 1 (SDF-1). J Exp Med 1996, 184:1101-1109.

45. Hayashi $H$, Kume T: Forkhead transcription factors regulate expression of the chemokine receptor CXCR4 in endothelial cells and CXCL12-induced cell migration. Biochem Biophys Res Commun 2008, 367:584-589.

46. Cruz-Orengo L, Chen YJ, Kim JH, Dorsey D, Song SK, Klein RS: CXCR7 antagonism prevents axonal injury during experimental autoimmune encephalomyelitis as revealed by in vivo axial diffusivity. J Neuroinflammation 2011, 8:170.

47. Arnett HA, Mason J, Marino M, Suzuki K, Matsushima GK, Ting JP: TNF alpha promotes proliferation of oligodendrocyte progenitors and remyelination. Nat Neurosci 2001, 4:1116-1122.

48. Brambilla R, Ashbaugh JJ, Magliozzi R, Dellarole A, Karmally S, Szymkowski $D E$, Bethea JR: Inhibition of soluble tumour necrosis factor is therapeutic in experimental autoimmune encephalomyelitis and promotes axon preservation and remyelination. Brain 2011, 134:2736-2754.

49. Lambertsen KL, Clausen BH, Fenger C, Wulf H, Owens T, Dagnaes-Hansen F, Meldgaard M, Finsen B: Microglia and macrophages express tumor necrosis factor receptor p75 following middle cerebral artery occlusion in mice. Neuroscience 2007, 144:934-949.

50. Wu J, Yoo S, Wilcock D, Lytle JM, Leung PY, Colton CA, Wrathall JR: Interaction of $\mathrm{NG2}(+)$ glial progenitors and microglia/macrophages from the injured spinal cord. Glia 2010, 58:410-422.

51. Foote AK, Blakemore WF: Inflammation stimulates remyelination in areas of chronic demyelination. Brain 2005, 128:528-539.

52. Hvilsted Nielsen $\mathrm{H}$, Toft-Hansen $\mathrm{H}$, Lambertsen $\mathrm{KL}$, Owens $T$, Finsen B: Stimulation of adult oligodendrogenesis by myelin-specific T cells. Am J Pathol 2011, 179:2028-2041.

53. Kostianovsky AM, Maier LM, Anderson RC, Bruce JN, Anderson DE: Astrocytic regulation of human monocytic/microglial activation. J Immunol 2008, 181:5425-5432.

54. Ubogu EE, Cossoy MB, Ransohoff RM: The expression and function of chemokines involved in CNS inflammation. Trends Pharmacol Sci 2006, 27:48-55.

55. Han Y, Wang J, He T, Ransohoff RM: TNF-alpha down-regulates CXCR4 expression in primary murine astrocytes. Brain Res 2001, 888:1-10. 
56. Patel JR, McCandless EE, Dorsey D, Klein RS: CXCR4 promotes differentiation of oligodendrocyte progenitors and remyelination. Proc Natl Acad Sci U S A 2010, 107:11062-11067.

57. Gottle P, Kremer D, Jander S, Odemis V, Engele J, Hartung HP, Kury P: Activation of CXCR7 receptor promotes oligodendroglial cell maturation. Ann Neurol 2010, 68:915-924

58. Wang $L$, Wang $Z$, Yang $B$, Yang $Q$, Wang L, Sun Y: CXCR4 nuclear localization follows binding of its ligand SDF-1 and occurs in metastatic but not primary renal cell carcinoma. Oncol Rep 2009, 22:1333-1339.

59. Farooque M, Isaksson J, Olsson Y: Improved recovery after spinal cord injury in neuronal nitric oxide synthase-deficient mice but not in TNF-alpha-deficient mice. J Neurotrauma 2001, 18:105-114.

60. Patel JR, Williams JL, Muccigrosso MM, Liu L, Sun T, Rubin JB, Klein RS: Astrocyte TNFR2 is required for CXCL12-mediated regulation of oligodendrocyte progenitor proliferation and differentiation within the adult CNS. Acta Neuropathol 2012, 124:847-860.

61. Kigerl KA, McGaughy VM, Popovich PG: Comparative analysis of lesion development and intraspinal inflammation in four strains of mice following spinal contusion injury. J Comp Neurol 2006, 494:578-594.

62. Sroga JM, Jones TB, Kigerl KA, McGaughy VM, Popovich PG: Rats and mice exhibit distinct inflammatory reactions after spinal cord injury. J Comp Neurol 2003, 462:223-240.

63. Trivedi A, Olivas AD, Noble-Haeusslein L: Inflammation and spinal cord injury: infiltrating leukocytes as determinants of injury and repair processes. Clin Neurosci Res 2006, 6:283-292.

doi:10.1186/1742-2094-10-92

Cite this article as: Bracchi-Ricard et al.: Inhibition of astroglial NF-

kappaB enhances oligodendrogenesis following spinal cord injury. Journal of Neuroinflammation 2013 10:92.

\section{Submit your next manuscript to BioMed Central and take full advantage of:}

- Convenient online submission

- Thorough peer review

- No space constraints or color figure charges

- Immediate publication on acceptance

- Inclusion in PubMed, CAS, Scopus and Google Scholar

- Research which is freely available for redistribution 